Yalova Sosyal Bilimler Dergisi

\title{
Tek Ebeveynli Ailelerin Sorunları: Nitel Bir Araştırma
}

Sevim ATILA DEMIR ${ }^{1}$

Şaziye GENÇ ÇELEBİ ${ }^{2}$

\begin{abstract}
Özet
Toplumsal değişim sürecinde günlük yaşamda ve ailede meydana gelen değişimler sonucunda tek ebeveynli ailelerin oranında artış yaşanmıştır. Tek ebeveynli aile ebeveynlerden birinin, çoğu zaman annenin, çocuğun bakımı ve sorumluluğunu tek başına üstlendiği aile biçimidir. Boşanma, eşlerden birinin vefatı veya tercih sonucunda oluşabilen tek ebeveynli ailelerin diğer aile biçimlerinden farklı sorunları bulunmaktadır. Bu araştırmanın amacı; tek ebeveynli ailelerin sorunlarını tespit etmek ve bu ailelere yönelik hizmetleri geliştirebilmek için veri sunabilmektir. Araştırma Kocaeli Büyükşehir Belediyesi'ne bağlı Beyaz Kalpler Eğitim ve Gelişim Merkezine devam eden tek ebeveyne sahip çocukların ebeveynleri ile yapılmıştır. Çalışmada yarı yapılandırılmış görüşme formu kullanılmış, derinlemesine mülakat yapılmış ve elde edilen veriler ekonomik sorunlar, sosyal sorunlar, çocuk ile ilgili sorunlar, ev işleri ile ilgili sorunlar ve psikolojik sorunlar olarak beş ayrı kategoride sınıflandırılmış̧ır.
\end{abstract}

Anahtar Kelimeler: Sosyal değişme, aile, tek ebeveynli aileler.

\section{The Problems of Single-Parent Families: A Qualitative Research}

\begin{abstract}
Durıng the process of social change, there has been an increase at the rate of single-parent families as a result of changes in families and daily lives. Single- parent family is a kind of which one of the parents, especially mother, takes the care and responsibility of the child alone. The family which can occure from the causes such as divorcement, the death of one of the spouses or preference has different problems than the other types of families. The aim of this research is to identify the problems of single-parent families and to present data for developing the services to these families. The research was carried out with the parents of the single- parent children continuing their part- time studies at White Hearts Training and Development Center dependent to Kocaeli Metropolitan Municipality. A depth interview was carried out with a semi-structured interview in this research and the obtained data was classified in five different categories as economic problems, social problems, child related problems, problems related with housework and psychological problems.
\end{abstract}

Keywords: Social change, family, single-parent families,

\section{Giriş}

Toplumun temel kurumlarından biri olan aile, aynı zamanda sosyal ve tarihsel bir olgudur ve her kurum gibi sosyal bütünün bir parçasıdır. Bir bütün olarak toplum düzeni ve toplumun diğer kurumları nasıl tarih içerisinde değişmeler geçirmişse, aile kurumu da toplum düzenine bağlı olarak değișim geçirmiștir. Bu bağlamda aile bir tarihsel ürün olarak ele alınmalı ve aile kurumunun ne tür değişimlerden geçtiği göz önünde bulundurulmalıdır. Kuşkusuz bu tarihsel değişimi, aile bireylerinin karşılıklı konumlarında ve buna bağlı olarak ailenin fonksiyonlarında ortaya çıkmış olan değişiklikler çerçevesinde değerlendirmek gerekir (Kızılçelik \& Erjem, 1994: 10). Günümüzde ailede geleneksel toplumdan modern topluma geçişte köklü değişimlerin yaşanmasını sağlayan en önemli etkenlerden biri sanayileşmenin kendisidir. Sanayileşme üretim biçimlerinin yanı sıra bütün toplumsal ilişkileri

${ }^{1}$ Doç. Dr., Sakarya Üniversitesi, Fen Edebiyat Fakültesi, Sosyoloji Bölümü, satila@ sakarya.edu.tr

${ }^{2}$ Yüksek Lisans Öğrencisi, Sakarya Üniversitesi, saziye.celebi@ ogr.sakarya.edu.tr 
kökten değiştirince bunun aile yapısı ve işlevleri üzerinde kaçınılmaz sonuçları olmuştur. Ailenin yaşadığı değişimlerin küresel ölçekteki durumu değerlendirildiğinde geniş aileler ve akraba gruplarının etkilerinin gittikçe azaldığ 1 (Aktay, 1991: 182-183) görülmektedir. Geleneksel ailenin dönüşümü ve çekirdek ailenin yaygınlaşma eğilimi göstermesi aslında modernleşmenin genel geçer hedefleriyle paralellikler taşımaktadır (Subaşı, 2014: 114). Ancak mutlak anlamda çekirdek aile tanımlaması gelenekselden moderne doğru ilerlediği varsayılan toplumlarda durumu tam olarak yansıtmamaktadır. Örneğin; Türk toplumunda en yaygın olarak görülen aile tipi bağlantılı çekirdek ailedir. Evlenen çiftler aynı zamanda geldikleri aileler ile olan ağlarını ve ilişkilerini devam ettirerek ailelerini bir nevi güvence altına almaktadırlar. Yeni evlenecek çiftlerin düğünlerinin aileler tarafindan yapılması, ailelerin evlilik sonrası da çiftlere maddi manevi destek vermeleri bu aile tipinin bir özelliğidir. Hatta bağlantılı çekirdek ailenin bir formu da bugün sıkça görülen aile apartmanlarıdır (Sarı, 2016: 95). Bu anlamda ailedeki yapısal dönüşümler kültürel ve toplumsal deneyimler çerçevesinde okunduğunda anlaşılabilecektir.

Ailenin yeni tipolojisi toplumun yeni genel kabulleri doğrultusunda yeniden oluşmuştur, böylece aile içinde hem erkeğe hem de kadına yüklenen roller zaman içerisinde dönüşmüş ve cinsiyet rollerinde daha eşitlikçi bir dağılım kendini göstermeye başlamıştır. Erkeğin güç ve otorite modeli olması, "sembolik anlam" taşımaya başlamıştır. Sözgelimi ev ve çocukların bakımıyla ilgili sorumluluklar kadına ait olmaktan çıktığı gibi, para kazanmak ya da ev dışında toplumsal bir yaşam sürdürmek gibi erkeğe özgü nitelikler de onun tekelinden çıkmıştır. Buna bağlı olarak evlilik stratejileri kademeli bir şekilde değişmiştir (Subaşı, 2014: 107). Kadının toplumsal konumunun iyileşmesi ve sosyal güvenliğin yaygınlaşması ailedeki değişimde etkili olmuştur. Aile ile ilgili karar alma sürecinde eşler arasındaki ortak karar alma ataerkil tekeli kıran bir gelişmedir. Eşin özgürce seçilmesi, evliliğin başlatılması, aile içindeki kararların verilmesi bakımından, kadın hakları daha çok tanınır olmuştur (Aktay, 1991: 183-187).

Endüstrileşme aşamasında en önemli ve kalıcı olgu artan uzmanlaşmadır. Uzmanlaşmanın sonucunda kurulan örgütler, kurumlar ve işletmeler ailenin yerine getirdiği fonksiyonları ve sorumlulukları azaltmıştır. Bu kurumlar ve örgütlenmeler hem toplumda bir hizmet fonksiyonu görmekte (Özkalp, 1993:119) hem de ailenin işlevlerinin önemli bir kısmını devralmaktadırlar. Örneğin; ailenin çocukları eğitme ve sosyalize etme işlevleri belli ölçülerde kurulum amacı bu işler olan başka kurumlara aktarılmış ve kendi üyeleri üzerindeki etkileri görece azalmıştır. Çocuğun ilk dönem sosyalizasyonu profesyoneller eliyle yürütülmeye başlanmıştır. Uzmanların kurallarıyla işleyen bu profesyonel sistem içinde çocukların özellikle kişiliklerinin tam da şekillenme döneminde kalıcı ve duygusal ilişkiler geliştirmeleri güçleşmektedir (Aktay, 1991:183-184). Kurumsallaşma ve uzmanlaşma ailenin işlevlerinin yeniden tanımlanmasına ve sonucunda yeni pratik ilişkilerin ortaya çıkmasına neden olmuştur.

Endüstriyel toplumdaki aile geçmişteki ailelere oranla mobilitesi daha yüksek ve otorite yapısı farklıdır. Günümüzde aileyi dışarıdan etkileyen çeşitli faktörler ortaya çıkmıştır. Örneğin çocuklar üzerinde arkadaş ve çevresi aile bireylerinden 
Yalova Sosyal Bilimler Dergisi

kimi zaman daha etkili olabilmektedir. Yine endüstrileşmeyle birlikte anne ve babanın ev dışında çalışmasıyla aile üyelerinin gün boyunca birlikte geçirdikleri sürenin azalmış olması, sosyal medya ve iletişim araçlarının gelişmesi ve yaygınlaşması aile üzerinde etkili olması aile üyelerinin iletişimlerinin azalmasına neden olmuştur. Ailede görülen başka bir değişim ise; kapitalizm ve sanayileşme öncesinde aile üretici bir birim olarak işlev görürken sonrasında tüketim alanı olarak işlev görmeye başlamıştır (Giddens, 1997: 112- Özkalp,1993: 120).

Bütün bu farklılaşmaların asıl noktasını modernleşmeyle ilişkilendirmek gerekir. Gerçekten de gelenekten modernliğe geçişin yarattığ çelişkiler ve huzursuzluklar aileyi ve onun ürettiği bağları bir dizi ilişkiyle karşı karşıya getirmiştir. Geleneksel hayattan modern hayata geçişte sosyal ve ekonomik düzeyin değişimi ile ortaya çıkan göstergeler, ailenin de kurumsal açıdan yeni bir biçim almasını hızlandırmıştır. Modern toplumda artık gelenekselleşmiş kabul edilen geniş ve çekirdek aile tipleri, yeni aile türleri ve aileye alternatif olarak ortaya çıkan yaşam biçimleriyle karşı karşıyadır. Nasıl geleneksel geniş ailenin çözülmesi modern çekirdek aileyi ortaya çıkarmışsa bu ailenin çözülmesi de yeni aile türlerine yol açmaktadır. Ancak bu yeni aile türleriyle birlikte ailenin bilinen tanımları da kökten değişmektedir (Walczak \& Burns, 2004:203). Tek ebeveynli aileler bu yeni aile biçimlerinden biridir. Tüm bu değişmelere paralel olarak ailede görülen önemli bir durum ise boşanma oranlarının artmasıdır. Bugün bakıldığında hemen hemen tüm ülkelerde boşanma gittikçe artan bir realite olarak karşımıza çıkmaktadır. Türkiye'de 2015 yılı TÜIKK verilerine göre boşanan çiftlerin sayısı bir önceki yıla göre \%0,7 artarak 131 bin 830 oldu. Kaba boşanma hızı binde 1,69 olarak gerçekleşti (TÜIK, 2015). Boşanma tek ebeveynli ailelerin oluşumunda en belirleyici nedenlerden biri olarak tanımlanmaktadır.

\section{Tek Ebeveynli Aile}

Aile kurumunun değişimi ve yeni aile formlarının ortaya çıkışı toplumsal değişimin ürünüdür. Görülen önemli değişimlerin başında tek ebeveynli ailelerin artış1 gelmektedir. Tek ebeveynli aile, bir ebeveyn ile yaşayan çocuk ya da çocuklardan oluşan aile olarak tanımlanmaktadır. Tek ebeveynli aile formunun ortaya çıkmasına neden olan etkenlere baktığımızda ebeveynlerden birinin ölümü, uzun süren ya da sürekli yokluğu veya boşanma ve tercih durumu gibi faktörler görülmektedir. Tek ebeveynli ailelerin, ebeveynlerin bir arada yaşadığı ailelere göre duygusal, psikolojik, sosyal ve ekonomik olarak farklılaşan ve benzerlik gösteren ihtiyaçları bulunmaktadır (Kalayc1, 2011: 17-18). Tüm dünyada ve ülkemizde boşanmaların hızla arttığı görülmektedir. Boşanmaların yarattığı en önemli sorunlardan birisi çocukların sorumluluğunun tek ebeveyn tarafından alınması ya da ebeveynlerin hiçbirinin sorumluluk almaması şeklinde olduğu görülmektedir. $\mathrm{Bu}$ durumun yaygınlığı sanayi ve post-sanayi toplumunun karakteristik bir özelliği haline gelmiştir (Aktay,1991:184). Boşanmanın yükselişiyle beraber Batı ülkelerinde de tek ebeveynli aile tarzı yaygınlaşmaktadır. OECD ülkelerinde tüm çocukların yaklaşık \%15'i tek ebeveynlidir. Bugün OECD ülkelerinde boşanmış ailelerin önemli oranı çocuk sahibidir (OECD, 2011). Tek ebeveynli ailelerin çoğunluğunu anneler ve çocukları oluşturmaktadır. Tek ebeveynli aile olmak anneleri akademik başarısızlığının yanında stres, dışlanma ve 
Yalova Sosyal Bilimler Dergisi

yalnızlaşma gibi riskler ile karşı karşıya getirmektedir. $\mathrm{Bu}$ anlamda özellikle olmayan babanın aile ilişkilerini zayıflattı̆ğ dikkat çekmektedir. Amerika'da artan boşanma oranları ile birlikte tek ebeveynli ailelerin oranında ciddi bir artış görülmektedir. Amerika'da doğan çocukların hemen hemen yarısının 18 yaşına girmeden en az bir süre tek ebeveynli ailede yaşayacakları öngörülmektedir (Çaki, 2016: 281).

Bugün İngiltere'de tek ebeveynli aileler 1 milyonun üzerindedir ve bu sayı giderek artmaktadır. Bakım gerektiren çocukların bulunduğu her beş aileden birisi böyle bir ailedir. Ortalama olarak, bunlar modern toplumdaki en yoksul gruplar arasından çıkmaktadır. Birçok tek ebeveyn daha önce evlenmiş olsun olmasın ekonomik zorlukların yanı sıra, toplum tarafından onaylanmama davranışıyla da karşılaşmaktadır. Bununla birlikte, daha önceki, "terk edilmiş kadın”, "babasız aileler" ve "dağılmış aileler" gibi daha yargı yüklü terimler giderek ortadan kalkmaktadır. Tek ebeveynli aile kategorisi, kendi içinde de farklılıklar gösteren bir kategoridir. Örneğin, boşanmış annelerin yarıdan fazlasının oturdukları evler kendilerinin olduğu halde, hiç evlenmemiş yalnız annelerin büyük çoğunluğu kirada oturmaktadır. Tek ebeveyn anlaşmazlık nedeni ile bir süreliğine yalnız kalmış ve kendi başına yaşamaya başlamışsa bu durumlarda ayrılığın kaçınılmaz olduğu görülmüştür. Bugün tek ebeveynli ailelerin \%60'1, ayrılma ya da boşanma sonucu bu duruma gelmişlerdir. İnsanların çoğunluğu yalnız ebeveyn olmanın zorlukları nedeniyle tek ebeveynli aile olmayı istememektedir fakat böyle olmayı seçenlerin sayısı da azımsanmayacak bir biçimde artmaktadır. Tek ebeveynli aile böyle bir aileyi başarıyla sürdürmek için yeterli ekonomik kaynağı bulunan kimi yalnız ebeveynler için tercih edilen bir aile tipidir. Evli olmayan ya da hiç evlenmemiş annelerin çoğunluğu için gerçek farklıdır. Evlilik dışındaki doğum oranları ile yoksulluk ve toplumsal konum düşüklüğü arasında yüksek bir ilişki bulunmaktadır (Giddens, 2000: 162-163). Türkiye'de ise toplam hane halklarının \%7,8'inde yalnız ebeveyn ve çocuklar yaşamaktadır. Toplam hane halklarının; $\% 1,6$ 'sı baba ve çocuklarından, \%6,2'si ise anne ve çocuklarından oluşmaktadır. Nüfusumuzun ise \%1,1'i baba ve çocuklarından oluşan hane halklarında yaşarken, $\%$ 4,6'sı anne ve çocuklarından oluşan hane halklarında yaşamaktadır (TÜIKK b, 2015).

Türkiye'de ve birçok ülkede boşanmalarda velayetin anneye verilmesi tek ebeveynli ailelerin çoğunlukla anne ve çocuklardan oluşmasında etkili olmaktadır. Tek ebeveynli ailelerde diğer ebeveynin yokluğu nedeni ile ailede kalan tek ebeveyn, olmayan ebeveynin görevlerini yerine getirmeye çalışmakta, sosyal, ekonomik ve psikolojik olarak daha fazla sorumluluk ve görev almaktadır. Tek ebeveynli aile formunun gittikçe artmasıyla, bu formda yaşanan zorlukları ve sorunları aşmayı ve/veya etkilerini azaltmayı hedefleyen sosyal politika önerilerini geliştiren çalışmalar da literatür de önemli bir yer tutmaya başlamıştır (Kalaycı, 2011: 20).

\section{Araştırmanın Metodolojisi}

$\mathrm{Bu}$ çalışmanın amacı tek ebeveynli ailelerin sorunlarını ortaya koymak ve ortaya çıkan sosyal, ekonomik ve psikolojik alanlardaki sorunların çözümüne yerel 
yönetimler bağlamında belediyelerin nasıl katkı sağlayacağına dair önerilerde bulunmaktır. Yapısal-işlevselci perspektif aileyi sistem ve işlevler arasındaki koordinasyona bağlı olarak işler. Aile üyelerinden birinin işlevini yerine getirmemesi sistemin işleyişini engeller, en azından zora sokar. $\mathrm{Bu}$ nedenle bireylerin rollerini yerine getirmesi ailenin istikrarı için son derece önemlidir. İşlevlerin yerine getirilmesine ve koordinasyonun derecesine göre ailevi bağlar güçlenir ve ortaya kendi işlevlerini yerine getiren sağlıklı bir yapı çıkar (Canatan, 2011: 39).

Tek ebeveynli ailelerde olmayan ebeveynin rolünün yerine getirilmesinden ve ortaya çıkan işlevsel eksikliğin üstlenilmesinden oluşan problemlerin incelenmesi nedeni ile bu perspektif bu çalışmada dikkate alınmıştır. Ekolojik perspektif odak noktasına insan ve çevresi arasındaki ilişkileri almıştır. Organizma ve sosyal varlık olarak insan kendi çevresiyle etkileşim içindedir. İnsan yaşamının kalitesi ve çevrenin kalitesi, karş1lıklı olarak birbirine etki eder. Ekolojik perspektif, aileyi çevresel değişimlere uyum sağlayan ve kendini yeniden örgütleyen bir sistem olarak tanımlar. İhtiyaçlarını karşılamak için aile ve aile üyelerinin yönetim ve iş bölümü açısından nasıl davranışlar gösterdiğiyle ilgilenir (Canatan, 2011: 37). Yine ekolojik perspektife göre; insanlar aile, kültür, alt kültür, toplum, okul gibi sistemlerden oluşan bir sosyal ağ içerisinde yaşamlarını devam ettirmektedir. Birbirine bağlı olarak sistem ve birimlerinde ki değişimler birbirlerini etkilemektedir. Örneğin aile içerisinde ebeveynlerin ilişkilerindeki değişim ailenin diğer bireylerini ve motivasyonlarını etkilemektedir (Bertalanffy (2004)'dan Akt. Danış, 2006: 46). Adaptasyon (Adaptation) ve Başetme (Coping) ekolojik perspektifin kullandığı temel kavramlardandır. Aile ve sosyal kurumların işlevi ve yapısı her geçen gün değişmekte ve birey için karmaşık hale gelmektedir. $\mathrm{Bu}$ durum bireylerin çevreye adaptasyonunu etkilemekte ve sorunlara yol açmaktadır. Örneğin; birey bir ebeveynin ani ölümü ya da yeni bir çocuğun dünyaya gelmesi gibi gelişmelerde nasıl davranacağı hususunda geçmişteki gözlemlerine ya da edinmiş olduğu tecrübelerine başvurur (Ashman ve Zastrow (1990)'dan; Ashman ve Hull (1999)'dan Akt. Danış, 2006: 52). Bu perspektifin odak noktası ve varsayımları dikkate alındığında, tek ebeveynli aile olmanın bireysel bir olgu olmadığı, toplumsal değişimlerin etkisi ile oluştuğu ve ailenin de bu süreçten sonra çevresel değişimlere uyum sağlamaya, kendini yeniden örgütlemeye çalıştı̆̆ görülmektedir. İhtiyaçlarını karşılamak için aile yeni duruma uyum sağlamakta ve bu amaçla yeniden dönüşmektedir. Yine ekolojik perspektife göre birey ve çevresi arasında bir denge kurularak olabilecek olası sorunlar önceden önlenebilmektedir. $\mathrm{Bu}$ çalışmada ekolojik perspektiften bu anlamda faydalanılmış ve bu çalışmada öneriler kısmı bu düşünceye dayandırılmıştır.

$\mathrm{Bu}$ çalışma nitel araştırma yöntemi ile yapılmıştır. Veri toplama aracı olarak mülakat tekniği kullanılmıştır. Betimsel analiz yöntemi tematik çerçeve kullanılarak gerçekleştirilmiştir. Bu amaçla, elde edilen veriler ekonomik sorunlar, sosyal sorunlar, çocuk ile ilgili sorunlar, ev işleri ile ilgili yaşanan sorunlar ve psikolojik sorunlar olarak beş ayrı kategoride sınıflandırılmıştır. Görüşmenin yönetilmesi ve konunun sınırlandırılması açısından görüşmelere önceden yarı biçimlendirilmiş sorular içeren bir görüşme formu ile gidilmiş ve derinlemesine görüşme yapılmıştır. Derinlemesine görüşmede amaç; aktörlerin tutum ve 
davranışlarının arkasındaki gerçek nedenlere ulaşabilmektir (Baş-Akturan, 2008: 111). Araştırmaya katılan katılımcılardan önceden randevu alınarak, görüşmeler katılımcıların uygun gördükleri yerlerde; katılımcıların evlerinde ve Kocaeli Büyük Şehir Belediyesine bağlı Beyaz Kalpler Eğitim ve Gelişim Merkezinde yapılmıştır. Görüşmeler katılımcının rızası ile kayıt cihazına kaydedilmiş ve çözümlemeler yapılarak raporlaştırılmıştır. Katılımcılarla daha önceleri birçok kez Beyaz Kalpler Eğitim ve Gelişim Merkezinde görüşüldügüunden ebeveynler araştırmacıyı önceden tanımaktadır ve güvenmektedir bu durum çalışmanın uygulama safhasını kolaylaştırmıştır.

Ana kütleyi temsil yeteneğine sahip örneklemin seçimi için birçok yol mevcuttur. Ancak ana kütleden onu temsil edebilecek birimleri ve bu birimlerden oluşacak örneklemi seçebilmek için evreni iyi tanımak, hakkında oldukça geniş bilgi sahibi olmak gerekir (Arslantürk, 1995: 87). Bu araştırma için on katılımcı seçilmiştir. Temsil edici alt grupların seçilmesi yoluna gidilmiştir. Alt grupların nasıl seçildiğinin veya örneklemin, araştırmanın sonuçlarının yorumlanabilme tarzı üzerine önemli bir etkisi vardır. Eğer incelenen kişiler kesin ve amaçlı bir strateji izlenerek seçilirse araștırma daha değerli olacaktır. Örneklemin nasıl seçilmesi gerektiği araştırmanın amaçlarına bağlıdır (Miller, 1996: 69). Amaçlı örnekleme daha büyük evrenin temsilcisi olarak düşünüldüğü için araştırmacı tarafından denekler özelliklerinden dolayı amaçlı olarak seçilmektedir (Miller, 1996: 73). Seçilen örneklemin evreni temsil yeteneğinin güçlü olması için, katılımcıların sahip oldukları demografik özelliklerin birbirinden farklı olmasına dikkat edilmiştir.

Araştırmanın evreni tek ebeveynli ailelerden oluşmaktadır. Araştırmanın örneklemi ise Kocaeli Büyükşehir Belediyesi Beyaz Kalpler Eğitim ve Gelişim Merkezine 2016-2017 yıllarında komisyon kararı ile kabul edilmiş, merkezden eğitim almış, İzmit, Derince, Gölcük ve Kartepe ilçelerinde ikamet eden tek ebeveyne sahip çocukların ebeveynleridir. Beyaz Kalpler Eğitim ve Gelişim Merkezi ise; okula devam etmeyen ve/veya devamsızlı yapan, aile içi problemleri bulunan, parçalanmış aileye sahip olan, sigara ve teknoloji bağımlılığ bulunan, şiddete maruz kalan ve/veya şiddete meyleden, öfke kontrolü problemi bulunan, davranım bozukluğu olan, ekonomik yönden istismar edilen, akran zorbalığı yapan, riskli sosyal ortamlarda bulunan, suça sürüklenmeye elverişli çocukların sorunlarının çözümü için devam ettiği bir eğitim merkezidir. Kocaeli Büyük Şehir Belediyesine ait Beyaz Kalpler Eğitim ve Gelişim Merkezinde tek ebeveynli aileye sahip çocukların ebeveynlerinin örneklem seçilme nedeni ise yeterli temsil gücünün bulunması ve araştırma maliyetinin az olmasıdır. Yalnız kadınlardan oluşan tek ebeveynlerle görüşme yapılmış olması Türkiye'de genel olarak tek ebeveynli ailelerin büyük çoğunluğunun anne ve çocuklarından oluşan aileler olmasından dolayıdır. Katılımcılar arasında üniversite mezunu bulunmaması araştırmanın sınırlılığını oluşturmaktadır.

\section{Bulguların Değerlendirilmesi}

Araştırmaya dâhil olan katılımcıların demografik özellikleri aşağıda tablolaştırılmıştır. 
Yalova Sosyal Bilimler Dergisi

Tablo 1: Katılımcıların Demografik Özellikleri

\begin{tabular}{|c|c|c|c|}
\hline & & Katılımc1 & Toplam \\
\hline \multirow{3}{*}{ Yaş } & 30 ve Alt1 & -- & \multirow{3}{*}{10} \\
\hline & $31-40$ & 7 & \\
\hline & $41-50$ & 3 & \\
\hline \multirow{5}{*}{ Eğitim Durumu } & Okur-Yazar değil & 1 & \multirow{5}{*}{10} \\
\hline & İlkokul & 5 & \\
\hline & Ortaokul & 3 & \\
\hline & Lise & 1 & \\
\hline & Üniversite & -- & \\
\hline \multirow{4}{*}{$\begin{array}{l}\text { İkamet } \\
\text { İlçe }\end{array}$} & İzmit & 7 & \multirow{4}{*}{10} \\
\hline & Derince & 1 & \\
\hline & Kartepe & 1 & \\
\hline & Gölcük & 1 & \\
\hline \multirow{2}{*}{ Gelir Durumu } & 4.546 Altı (YSA) & 8 & \multirow[b]{2}{*}{10} \\
\hline & 4.546 Üstü (YSÜ) & 2 & \\
\hline
\end{tabular}

Araştırma 10 katılımcı ile gerçekleştirilmiştir. Katılımcıların 7'si 31-40 yaş, 3'ü ise 41-50 yaş aralığında bulunurken 30 yaş ve altı katılımcı bulunmamaktadır. Katılımcıların eğitim durumları değerlendirildiğinde 1'i okuma-yazma bilmemektedir, 5'i ilkokul mezunu, 3'ü ortaokul mezunu 1'i ise lise mezunudur. Katılımcıların arasında üniversite mezunu bulunmamaktadır. Katılımcıların ikamet durumuna baktığımızda 7'si İzmit'te, 1'i Derince'de,1'i Kartepe'de, 1'i ise Gölcük'te ikamet etmektedir. Katılımcıların ekonomik düzeyi TÜiK ve KamuSen'in 2016 yoksulluk araştırmaları ölçü alınarak, yoksulluk sınırının altı (YSA), yoksulluk sınırının üstü (YSÜ) şeklinde belirtilmiştir. Araştırmaya katılan 10 ailenin 6' sının boşanma, 2' sinin eşin evden ayrılması (ceza evinde olması), 2' sinin ise eşlerinin vefat etmesi nedeni ile tek ebeveynli aile biçimini aldıkları görülmüştür.

Tablo 2: Tek ebeveynli ailelerin sorunları

\begin{tabular}{|c|c|c|c|c|}
\hline Ekonomik Sorunlar & $\begin{array}{l}\text { Sosyal } \\
\text { Sorunlar }\end{array}$ & $\begin{array}{l}\text { Çocuklarla İlgili } \\
\text { Sorunlar }\end{array}$ & $\begin{array}{l}\text { Ev İşleri İle } \\
\text { İlgili Sorunlar }\end{array}$ & $\begin{array}{l}\text { Psikolojik } \\
\text { Sorunlar }\end{array}$ \\
\hline $\begin{array}{l}\text { Daha önce çalışmayan } \\
\text { kadınların aile biçimi } \\
\text { değiştikten sonra } \\
\text { çalışmak zorunda } \\
\text { kalması. Meslek Sahibi } \\
\text { olamama nedeniyle } \\
\text { vasıfsız işlerde çalışma. } \\
\text { İşsizlik. Ev kirasını ve } \\
\text { borçları ödeyememe. } \\
\text { Çocukların ihtiyaçlarını } \\
\text { karşılayamama ya da } \\
\text { kısmen karşıyabilme. } \\
\text { Bağlanan nafakaların } \\
\text { tahsil edilememesi. } \\
\text { Çeşitli kurumlardan } \\
\text { yardım alarak geçimini } \\
\text { sağlama. }\end{array}$ & $\begin{array}{l}\text { İş çevresinde } \\
\text { rahatsız edilme. } \\
\text { Dışlanma. } \\
\text { Herhangi bir } \\
\text { aktivite, kurs ve } \\
\text { benzeri } \\
\text { faaliyetlerde } \\
\text { bulunamama. } \\
\text { Kendini sosyal } \\
\text { hayattan çekme. }\end{array}$ & $\begin{array}{l}\text { Çalışan kadınların } \\
\text { küçük çocuklarını } \\
\text { bırakacak } \\
\text { kimselerinin } \\
\text { olmaması. } \\
\text { Ebeveynlerin } \\
\text { çocuklar üzerinde } \\
\text { kısmen kontrol } \\
\text { sağlaması veya hiç } \\
\text { sağlayamaması. } \\
\text { Çocuklarda sosyal ve } \\
\text { psikolojik sorunların } \\
\text { oluşması. Çocukların } \\
\text { öğrenimlerini yarıda } \\
\text { bırakması. }\end{array}$ & $\begin{array}{l}\text { Çalışan } \\
\text { kadınların ev } \\
\text { işlerinde } \\
\text { kısmen } \\
\text { yardıma } \\
\text { ihtiyaç } \\
\text { duymaları ve } \\
\text { erkek işi } \\
\text { olarak } \\
\text { tanımlanan } \\
\text { tadilat, tamirat } \\
\text { konularında } \\
\text { sorun } \\
\text { yaşamaları. }\end{array}$ & $\begin{array}{l}\text { Psikolojik } \\
\text { desteğe } \\
\text { ihtiyaç } \\
\text { duyma, } \\
\text { ekonomik } \\
\text { nedenlerle ve } \\
\text { çalışan } \\
\text { kadınların } \\
\text { sınırlı } \\
\text { zamanları } \\
\text { olması } \\
\text { nedeniyle } \\
\text { yardım } \\
\text { alamama. }\end{array}$ \\
\hline
\end{tabular}


Yalova Sosyal Bilimler Dergisi

Tek ebeveynli ailelerin kendi içlerinde de oluşum nedenlerine göre farklı sorunları olduğu gözlenmiştir. Örneğin; Boşanma ve ayrılık nedeni ile oluşan ailelerin problemleri, vefat nedeniyle oluşan ailelerin problemlerine göre farkl1lık göstermektedir.

\subsection{Ekonomik Sorunlar}

Tek ebeveynli ailelerde ekonomik sorunların öncelikli ve önemli olduğu görülmüştür. Ebeveynlerin yaşamlarını yalnız devam ettirmeye karar verdiklerinde ekonomik gelirlerinde bölünme ve düşüş olmakta, bu durum ailenin yaşam standardını olumsuz etkilemektedir. Başka bir ekonomik sorun ise; araştırmaya katılan katılımcıların evli oldukları dönemden -özellikle eski eşlerinden- kalan borçları ödemek zorunda kalmaları, ödeme konusunda zorluk çekmeleridir. Borçlar genellikle kira, telefon, elektrik, su, kredi kartı ve kredi borçlarından oluşmaktadır.

\section{Katılımcı 6:}

“...Eşimden ayrllırken bankadan kredi çekmek zorunda kaldım avukat tutmak için boşanma davasını ben açtım, sonra bu borcu ödemekte zorlandım..." (40, Ilkokul, İzmit, YSÜ)

\section{Katılımeı 2:}

“...Elektrik su ve kira borcum var...” (41, Illkokul, Derince, YSA)

Aileler Aile ve Sosyal Politikalar İl Müdürlüklerinden, bulundukları ilçelerin kaymakamlığından ve yine bulundukları il ve ilçe belediyelerinden ayni ve nakdi yardım almaktadırlar. Eşi vefat eden kadınların ise vefat eden eşlerinden maaş aldıkları görülmüş̧ür. Araştırmaya katılan katılımcılardan yalnızca 1'i gurur yaptığını ve yardım çıktığı halde yardım almadığını ifade etmiştir.

\section{Katılımci 2:}

“...yardımlar almaya başladım, kaymakamlıktan nakit yardımı, gıda yardımı aldım, eşim cezaevindeyken Aile ve Sosyal Politikalar Il Müdürlügü̈ne başvurarak... Çocuk yardımı aldım... Büyük Şehir Belediyesinden gıda yardımı... Çocuklara giyim yardımı alıyorum, eğitim yardımı alıyorum, yine belediyeden sıcak yemek yardımı alıyorum, kaymakamlıktan kömür alıyorum şu anda bu şekilde geçiniyorum..." (41,illkokul, Derince, YSA)

Katılımcılar boşanma sonrası mahkeme kararı ile bağlanan nafakaları alamadıklarını eski eşin düzenli bir işi olmaması nedeni ile hukuksal bir işlem yapamadıklarını ve nafakayı tahsil edemediklerini ifade etmişlerdir.

\section{Katılımci 6:}

“...nafaka verecekti vermedi, hala vermiyor...” (40, İlkokul, İzmit, YSÜ)

\section{Katılımcı 10:}

“Aylık 650 tl nafaka bağlandı, onu da düzenli alamıyorum..." (34, İzmit, İlkokul, YSA) 
Yalova Sosyal Bilimler Dergisi

İşsizlik, çalışmak istenmesine ve bu amaçla iş aranmasına rağmen iş bulunamamasıdır (Odabaşı, 2009: 26). Annenin evlilik süresince vasıflı bir işte çalışmamış olması meslek sahibi olmaması iş bulma konusunda sıkıntı yaratmaktadır, işsizlik en büyük ekonomik sorundur. Katılımcılar evli oldukları süreçte çalışmadıklarını, boşandıktan/eşi vefat ettikten sonra çalışmak zorunda kaldıklarını bildirmişlerdir.

\section{Katılımcı 10:}

“...Boşanmak istiyordum fakat meslek sahibi değildim, çalışmam gerekiyordu bu nedenle sürekli öteledim...” (34, İzmit, İlkokul, YSA)

\section{Katılımcı 6:}

“...Boşandıktan sonra çalışmak zorunda kaldım...” (40, İlkokul, İzmit, YSÜ)

\section{Katılımcı 7:}

"Eşimle birlikteyken çalışmıyordum... Ayrıldıktan sonra bir işe girdim, eski eşim iş yerine geldi beni tehdit etti, yolda beni dövdü, karakolluk olduk, bir süre çalışmadım sonra ev temizliklerine gitmeye başladım” (37, Ortaokul, İzmit, YSA)

Ebeveynler genellikle, geçici, sosyal güvencesiz ve part time işlerde çalışmaktadırlar, Belediyelerin park bahçelerinde mevsimlik ağaç dikimi, gündelik temizliğe ve ütüye gitme, servis elemanlığı yapma, lokantalarda bulaşı yıkama gibi işleri yapmaktadırlar. Günümüzde dünya ülkelerindeki milyonlarca kadın çoğunlukla kayıt dışı, sigortasız sosyal güvencesiz, iş saatlerinin belirsiz olduğu şartlarda çalışmakta ve ev işçiliği yaparak yaşamını devam ettirmeye çalışmaktadır. Enformel çalışma tarzı olarak tanımlanan evde iş yapma (ev işçiliğii) dünyada olduğu gibi Türkiye'de de gittikçe artmaktadır (Dinçoflaz, 2009: 72). Ev işi ücretli veya ücretsiz "kadın işi”" olarak tanımlanır. Bu çerçevede ev işinin değersiz olarak görülmesi, bu işlerin elle tutulur olmaması ve çabuk tüketilmesi ile görünmez hale gelmiştir. Ev ve bakım işleri, toplum içindeki konumu açısından bakıldığında kapitalist üretim ilişkilerinin gizli zeminini ve yeniden üretim alanını oluşturur. Ev içi emek toplumsal olandan ziyade "doğal" alan üzerine kurulan ve mesai saatleri tanımlamasına dâhil olmadığı için ev içi işin miktarı da tanımlanamadığı için "görünmeyen ve karşıllıssız emek" olarak tanımlanır (Acar Savran- Demiryontan, 2012: 10-15). Bu alan ücretli olarak tanımlansa dahi enformel ikincil piyasa işleri olarak çoğunlukla kadınlar tarafından yapılmaktadır (Dedeoğlu, 2000:139). Bu durum birden fazla dezavantajlılığ doğurmakta ve tek ebeveynli ailelerde ekonomi kaynaklı güçlükleri derinleştirmektedir.

\section{Katılımcı 7:}

"Ev temizliklerine gittim, hala gidiyorum, biraz ailem destek oluyor, o parayla çocuklarımın ihtiyaçlarını karşıllyorum, geçiniyorum kardeşim elektriğimi suyumu ödüyor diğer kardeşim mutfak masraflarında destek oluyor." (37, Ortaokul, İzmit, YSA)

Çalışmak zorunda kalan küçük çocuğa sahip kadınlar çocuklarını bırakacak bir yer bulmakta güçlük çekmektedirler. Ülkemizde de çocuk bakımı kadının çalışma yaşamına katılımında ve sürdürmesinde olumsuz bir etken olarak 
Yalova Sosyal Bilimler Dergisi

tanımlanmaktadır. Bu anlamda iş yaşamı ve çocuk bakımı arasındaki sorunlar ailelerin kendileri tarafından çeşitli şekillerde çözülmektedir. Öncelikli olarak ebeveynler ailelerinden destek almakta, bu destek olmadığında kurumlardan hizmet almakta veya anne bir süre çalışmaya ara vermektedir. Başta İsveç’te olduğu gibi bebek bakımı ve çalışma sorunlarını azaltıcı hizmetler ücretsiz olarak ülkemizde sunulmamaktadır (Canatan, 2011b: 223).

\section{Katılımei 6:}

“...Eşsimden ayrıldığımda, büyük kızım 12 yaşındaydl, 12 yaşındaki bir çocuğa 4 ve 7 yaşındaki çocukları teslim ettim işe gittim, sabahtan gece 12'ye kadar çalışmak zorundaydım..." (40, Illkokul, İzmit, YSÜ)

\section{Katılımci 9:}

“...Oğlumla çalışmakta sıkıntı yaşadım, oğlum için sigortalı çalıştı̆̆ım işi bıraktım cafeler de çallş̧ım onunla ilgilenebilmek adına part time çalıştım, evlere temizliğe gittim annemin çalışmadı̆̆ kardeşime bıraktım gittim” (33, Lise, Gölcük, YSÜ)

\section{Katılımci 2:}

"Sürekli çalı̧̧acak bir işe giremiyorum en küçük oğlumu bırakacak bir yerim yok, annem var ama annem de çok yaşlı olduğundan dolayı gidip gelemez bize, aramızda bayă̆ı mesafe var, çocuklarımı mağdur etmemek için bir işe giremiyorum..." (41, İlkokul, Derince, YSA)

Ailelerin ekonomik durumlarının zayıf olması nedeni ile alamadıkları mal ve hizmetleri mümkün olduğunca emek ve hammadde kullanarak kendi imkânları ile üretmesi veya bu mal ve hizmetin yerine başka bir alternatifi ikame etmesi geçim stratejileri olarak adlandırılmaktadır. Aile üyelerinin dışarıdan alacağı hizmetlerin ev içinde verilmeye çalışılması, çocukların sosyalizasyonu, hasta ve yaşlıların bakımı gibi. Oturulan konutların tadilat ve tamiratlarının ailenin bireyler tarafindan yapılması, konutların bahçelerinde küçük hayvancılık ve tarımsal faaliyetlerin yapılmasıdır (Dinçoflaz, 2009: 117-118). Tek ebeveynli aileler gelirlerindeki düşüşten sonra geçim stratejileri uygulamışlardır. Örneğin ikamet ettikleri evin tadilat ve tamiratlarını kendileri yapmaya veya yakın akrabalarına yaptırmaya çalışmaktadırlar.

Boşanma ile oluşan tek ebeveynli ailelerde kadınlar özellikle boşanmadan sonra kendi ailelerine dönmekte ve onlardan destek almaktadır. Katılımcıların 5'i ailelerinden destek aldıklarını, diğer 5'i ise ailelerinin bir katkısının olmadığını ifade etmiştir. Ailelerinden destek gören ebeveynlerin psikolojik olarak kendilerini daha iyi hissettikleri ve kendilerini güçlü buldukları görülmüştür.

\section{Katılımcı 3:}

"Babam öldügü̈nde ben on yaşındaydım, babam öldükten sonra ben kendimi eksik hissettim o evde kendimi istenmezmiş gibi hissettim, neden öyleydi bilmiyorum, hâlbuki üveylik yoktu bir şey yoktu... İneklerimiz vardı ineklere birlikte bakardık ama annem çocuğumu istemiyordu, çocuğuma bir bardak süt vermezdi. 'Kapımda düşman beslemem' derdi. "(36, İzmit, Illkokul, YSA) 
Yalova Sosyal Bilimler Dergisi

\section{Katılımcı 9:}

"Boşanınca ailemin yanına taşındım hala da onlarla yaşıyorum ev kirası elektrik su ödemiyorum çalışıp çocuğumun ihtiyaçlarını karşıllyyorum” (33, Lise, Gölcük, YSÜ)

Araştırmaya konu olan ailelerde kadınların ekonomik olarak çocuklarının ihtiyaçlarını karşılayamadıkları ya da karşılamakta zorlandıkları görülmüştür.

\subsection{Sosyal Sorunlar}

Görüşülen kadınlar ekonomik nedenlerden ve zaman bulamadıklarından dolayı bir kursa gidemediklerini sosyal aktivitelere katılım sağlayamadıklarını, kendilerinden önce çocuklarını düşünerek davrandıklarını ifade etmişlerdir. Yapılan faaliyetler ise imkânlar dâhilinde gerçekleşmekte ve süreklilik arz etmemektedir.

\section{Katılımeı 6:}

"Çoluğumu çосй̆umu alıyorum bir sahil kenarına bir pikniğe gidiyoruz, geziyoruz, eğleniyoruz kışın mangallarımızı alıp gidiyoruz orada yiyip içiyoruz." (40, Illkokul, İzmit, YSÜ)

\section{Katılımcı 9:}

"Alış-veriş merkezlerine gidiyoruz yemeğe gidiyoruz, çok özel şeyler değil ama arabam olmadiğı için götürebileceğim yerlere götürüyorum, sinemaya götürüyorum, kendimle alakalı hiçbir faaliyetim yok, çocuğumdan dolayl” (33, Lise, Gölcük, YSÜ)

İnsanların günlük hayatında önemli yer tutan dürüstlük, arkadaşlık, bireyler ve aileler arasındaki sosyal ilişkiler sosyal sermaye birikimleridir. Bu birikimler sosyal ihtiyaçların karşılanmasını ve yaşam koşullarındaki gelişimi sağlamaktadır. Çeşitli nedenler ile kurulan ilişkilerin gücünü kaybetmesi bu birikimin azalmasına yol açar (Woolcock-Narayan, 1999: 5). Boşanma sosyal sermayeyi olumsuz etkileyen en önemli ailevi faktörlerdendir. Boşanan birey aynı zamanda ilişki ağlarını da bırakmak durumunda kalabilir. Bu durum ise kişinin güven duygusunu zedeleyebilmekte ve sosyal etkileşimleri negatif yönde etkilemektedir (Atila Demir, 2011:913). Nitekim 2014 yılında Türkiye'de boşanmış kişiler üzerinde yapılan çalışmanın sonuçlarına göre, eşinden ayrılmış kadınlar sosyal ilişkilerinde de kendi kendilerine kısıtlama getirmekte bu şekilde kendilerini güven altına almak istemektedirler (TBNA, 2014). Görüşülen kişilerin ifadelerine göre eş, dost ve akrabalar eşinden ayrılmış ebeveynlere göre eşi ölmüş ebeveynlere daha olumlu yaklaşmakta ve destek vermektedir.

\section{Katılımcı 6:}

"Ben şu anda komşunun evine gidemem, gitsem de evli bir kadın kadar rahat edemem, evliyken komşumun evine gittiğimde çok rahattım, aklımdan bir şey geçmezdi şimdi ise acaba eşi gelecek mi, acaba bir şey olacak mi gibi düşüncelerim oluyor, diken üzerinde duruyorsun” (40, Illkokul, İzmit, YSÜ) 
Yalova Sosyal Bilimler Dergisi

Bazı durumlarda kişilerin kendilerini sosyal etkileşimlerinde kısıtlaması olumsuz çevresel etkenler nedeni ile gerçekleşmektedir. Kadınlar yeni bir çevreye veya işe girdiklerinde tek ebeveyn olduklarını söylemekten çekinmektedirler.

\section{Katılımcı 1:}

"Lokantada çalışmaya başladım, en başta patronum beni rahatsı etti, gelen müşteriler asıllyordu ben yılmıştım, hayat mücadelesi veriyordum. Sadece kızıma bakayım, çalışayım gelirim olsun diyordum. Ama insanlar öyle düşünmüyordu... Genç bir bayan dulsa rahatsız edilmeyecek diye bir şey yok, rahatsı edilmeme gibi bir durumu yok, ben siknldım, bir dönem depresyona girdim. Eve kapattım kendimi..." (33, Illkokul, İzmit, YSA)

\section{3. Çocuklarla İlgili Sorunlar}

Anne ve babası ayrılmış çocukların psikolojik sorunlar açısından daha fazla risk altında olduğu bilinmekle birlikte bu konuda genellemelere varmak oldukça güçtür. Çünkü çocukların boşanmadan nasıl ve ne şekilde etkilendiği kişiye, duruma ve çocuğun yaşına göre değişmektedir. Aynı zamanda bu değişkenler boşanma sonrası çocukların ve ebeveynlerin yaşadıkları sıkıntıları da etkilemekte ve belirlemektedir. Boşanma durumu, psikolojik, sosyal ve ekonomik açılardan çok ciddi değişikliklere neden olmakla birlikte ebeveynleri boşanan çocukların, boşanma sonrasındaki kısa ve uzun dönemde akademik, sosyal ve psikolojik açılardan dezavantajlılıklar ile karşı karşıya kalabilmektedirler. Uzmanlar ayrılma sürecinden olumsuz etkilenen çocukların kullanılarak eski eşlere ceza verme şekline dönüşmemesine vurgu yapmaktadır (Atila Demir, 2016: 251- Öngider, 2013: 140). Katılımcılardan boşanmış kadınların 6'sı çocukları üzerinden eski eşleriyle ilgili problemlerin devam ettiğini bildirmiştir. 10 katılımcıdan 6'sının eski eşi çocukların ihtiyaçlarına destek olmamakta sadece 2 katılımcının eski eşi destek vermektedir.

\section{Katılımcı 10:}

“...Boşandıktan sonra 4 yıldır hiçbir ayımı rahat geçirmedim..." (34, İzmit, İlkokul, YSA)

“...Çocuğunuzun ayakkabısı eskir o ayakkabı ile dışarı çıkarsa üzülürsünüz içiniz acır, ama baba boşandiktan sonra böyle hissetmiyor. Onun çocuğu değilmiş gibi mecbur hissetmiyor kendini..." (34, İzmit, İlkokul, YSA)

Beyaz Kalpler Eğitim ve Gelişim Merkezi'ne devam eden tek ebeveyne sahip çocukların genellikle mutsuz, üzgün ve agresif oldukları, olmayan ebeveyn nedeniyle eksiklik duygusu yaşadıkları gözlenmiş bu bilgiler araştırmaya katılan ebeveynler tarafından doğrulanmıştır. Ebeveynin kadın olduğu ailelerde en büyük erkek çocuk bir süre sonra kardeşler için baba rolünü ve otoritesini üstlenmeye çalışmaktadır. Kız çocuklarının büyük olduğu ailelerde ise anne çalışıyorsa kız çocuk kardeşleri ile ilgilenmektedir.

\section{Katılımeı 2:}

"Yeri geldi en büyük oğlum kardeşlerine baba oldu. ..." (41, İlkokul, Derince, YSA) 
Yalova Sosyal Bilimler Dergisi

Katılımcıların çocukları eğitime devam etmemekte ve bir işte çalışarak aile ekonomisine katkıda bulunmaktadırlar. Yoksulların yoksulluk karşısında iki tür tepkileri vardır: İsyan etmek ve başa çıkmaya çalışmak. Ailede daha fazla kişinin iş gücüne katılması kadın ve çocukların çalışmaya başlaması bu stratejilerdendir (Dinçoflaz, 2009:116-117) Babanın olmadığı evlerde çocukların çalışmak zorunda kaldıkları ve eğitimlerini aksattıkları veya eğitimlerini bıraktıkları ya da örgün eğitimi bırakarak açık liseden eğitim hayatına devam ettikleri görülmektedir.

\section{Katılımeı 7:}

"Büyük klzım çalışlyor eve destek oluyor" (37, Ortaokul, İzmit, YSA)

ILO'nun yaptığı araştırmalara göre çocuklar, aile içindeki ekonomik sıkıntıyı bir nebze olsun azaltmak, temel ihtiyaçlarını kendi karşılayıp, ailenin yükünü azaltmak düşüncesi ile çalışma hayatına girmektedir. Çocukların eğitimlerini bile yarıda kesip çalışmaya başlamalarındaki sebep tamamen ekonomiktir (Ören, 2011:167). Ebeveynlerde babanın yokluğu nedeniyle çocukları üzerinde bir denetim kuramayacakları, otorite sağlayamayacakları ve çocuklarını kaybedecekleri hissinin hâkim olduğu gözlenmiştir. Bu nedenle annelerin birleştirici ve bütünleştirici işlevleri bulunmakta ve bu durum var olan sorumluluklarını bir kat daha artırmaktadır. Bu nedenle katılımcıların bazıları çocuklarını kontrol altında tutmak için çalışmadıklarını, çocuklarını kaybetmek istemedikleri için evde kalıp çocuklarına baktıklarını, yardımlarla hayatlarını idame ettirdiklerini belirtmişlerdir.

\section{Katılıme 4:}

"Çocuklarımın bir taşkınlığı yok ama saat on buçukta gelsin on birde gelsin, sanki ipin ucu kaçacakmış gibi hissediyorum, 'anne biraz daha dışarıda kalayım' dediğinde ve isteği olmadı̆̆ an kopup gidecekmiş gibi, çocuklar kötü yola düssecekmiş gibi his oluyor içimde, değişik bir his var gibi" (39, İlkokul, İmit, YSÜ, Kaylt 14)

\section{Katılımeı 5:}

"Şehirdir, biraklp bir yere gitsem korkuyorum bu yüzden bir yere gitmiyorum... Çocuklarıma sahip olmaya çalışıorum." (41, Eğitim Yok, YSA, Kartepe).

Ayrıca çocuklarda öfke kontrolü problemi, şiddete eğilim, riskli sosyal ortamlarda bulunma, okula devam etmeme, okuldan kaçma, eğitimi yarıda bırakma eğilimi, herhangi bir işte devamlılık gösterememe, sigara ve/veya teknoloji bağımlılı̆̆ intihara teşebbüs gibi sıkıntılar tespit edilmiştir. Aynı zamanda çocukların babaları ile az görüştügü (veya sadece ayaküstü görüştükleri) ifade edilmiştir.

\section{Katılımcı 4:}

"Baba cezaevinde olduğu için çocuklar görüşmüyor, önceden de zaten gelip çocuklarını kapı önünde gören bir babaydı" (39, İlkokul, İzmit, YSÜ, Kayıt 14) 
Yalova Sosyal Bilimler Dergisi

\section{Katılımcı 7:}

“...Büyük kızım çocukları Cumartesi Pazar çarşıya götürüyor babalarına gösteriyor, önceden kapıya geliyordu hır gür çıkarıyordu..." (40, İlkokul, İzmit, YSÜ)

Ebeveynler çocukları ile iletişim problemi yaşadıklarını, boşanmaya olumsuzluk atfedildikçe çocukların olumsuz tepki verdikleri belirtilmiştir. Dolayısı ile açık ve net kuralların olmadığı bir aile ortamı gençlerin ruh sağlığını olumsuz yönde etkilemektedir (Atakan- Korkut, 1994:196). Geleneksel olarak otorite baba üzerinden tanımlandığında babanın yokluğu birtakım sorunların kaynağı olarak tanımlanmaktadır.

\section{Katılımeı 1:}

"Kızım beni dinlemiyor, bir şey söylüyorsun hiç, sanki duvara söylüyorsun... oğlum bu son dönemlerde çok değişti herhalde evde yaşanan olumsuz şeylerden dolayı çok agresif, ne yaparsam yapayım olmuyor. Çok bağırıyorum, vurmamak için bağırıyorum, artık çok burama geldiği zaman şöyle (eliyle küçük bir vurma olduğunu anlatıyor) vuruyorum ama onu bile kaldıramıyor ki çocuk” (33, İlkokul, Izmit, YSA)

\section{Katılımcı 10:}

"Otorite falan yok, baba olmayınca çocuklar sizi insan yerine koymuyorlar, anne değilsiniz sanki arkadaşısınız ikisininde, şöyle: ben eve çalışıyorum tek çalışlyorum tamam baba zoraki de olsa katkıda bulunuyor ama ben hem dışarıda çalışlyorum erkek görevimi yapıyorum hem evde yemek ve maddi manevi destek sağllyorum. Bunun asla bir geri dönüşü yok, otorite falan yok. ” (34, İzmit, İlkokul, YSA)

\subsection{Ev İşleri ile İlgili Sorunlar}

Katılımcılar ev ile ilgili faaliyetlerinde bir problemlerinin olmadığını çalıştıkları süreçlerde de ev işleri konusunda çocuklarından kısmen yardım aldıklarını belirtmişlerdir. Ev tadilatı ve tamiratı konularında katılımcıların kadın olması nedeni ile yardıma ihtiyaç duyduklarını, ekonomik nedenlerle dışarıdan profesyonel yardım almak yerine akrabalardan veya ailenin büyük erkek çocuklarından yardım aldıklarını belirtmişlerdir. Ev işlerinde genellikle kız çocuklarından yardım alındığı belirtilmiştir.

\section{Katılımeı 7:}

"Çocuklar okuldan gelince ev işlerinde yardım ediyorlar hangisi erken gelirse bana el attyorlar... "(37, Ortaokul, İzmit, YSA)

\subsection{Psikolojik Sorunlar}

Katılımcıların 8'i boşanma/ve eşin vefatı sonrası psikolojik yardım almışlardır, almayan 2 katılımcı ise maddi imkânlardan dolayı alamadıklarını fakat ihtiyaç duyduklarını belirtmiştir. 
Yalova Sosyal Bilimler Dergisi

\section{Katılımci 3:}

"Boşandıktan sonra işimi bıraktım, kendimi bir işe yaramaz hissettim, işe elverişli olmadiğımı hissettim. Çok kötü bir şey... Kendimi hiç işe veremedim. Sanki birine çatacak gibiydim, ondan sonra psikoloğa gittim. İki üç ay devam ettim, düşündüm, kendi kendime dedim 'Kimse senin yarana merhem olmaz, ne ilaç ne doktor, 'toparlan çocukların var'. Bazen bir bardağl kaldiracak gücüm ve cesaretim olmuyor, ellerim falan titriyor, bazı şeyler aklıma geldiği zaman oluyor, tekrar psikoloğa gittim, ilaç kullaniyorum.” (36, Ilkokul, İzmit, YSA, Kayıt 13)

Boşanmadan sonraki yas döneminin hemen akabinde ikinci ergenlik olarak adlandırılan süreç başlamaktadır. Kişi bu süreçte ergenlik dönemine benzer bir kimlik bulma sorunu ile yüz yüze gelmektedir. Gündelik yaşama geçildiğinde kaybedilenin yalnızca bir eş değil, bir yaşam biçimi ve kimlik olduğu görülür. Eşinden ayrılan birçok insan gelecekten ve yalnızlıktan korkmaya, kim olduğunu ve ne olacağını bilememek gibi kaygılar yaşamaya başlar. Kişide başarısızlık duyguları, gelecekle ilgili beklentilerin gerçekleşemeyeceği inancı oluşur, mutlu beraberliklere imrenmeye, kötümserliğe ve benlik saygısının azalmasına yol açabilir (Atakan, 1991: 550).

\section{Katılımci: 8}

“...eşimin hasta olduğu süreçte ve vefatından sonra psikolojik yardım aldım, 1,5 yıldır ilaç kullanıyorum." (45,Ortaokul, İzmit, YSA,)

\section{Katılımcı 10:}

"Benim çocuklarımın psikolojik yardıma ihtiyacı olduğunu düşünüyorum, bu da mümkün değil, maddi sebeplerden dolayl, özel bir kliniğe götürmek istiyorum, iki çocuğu her ay götürdüğ̈̈mde bütçemi epey sarsar." (34, İzmit, İlkokul, YSA)

\section{Sonuç ve Öneriler}

Toplumsal değişme süreci ile birlikte ailedeki değişimlerden biri de tek ebeveynli ailelerdeki artış olarak gösterilebilmektedir. Tek ebeveynli ailelerin ihtiyaçlar çerçevesinde diğer aileler ile karşılaştırıldıklarında daha farklı bir iç iletişimin ve işlevinin gerçekleştiği görülmektedir. Ancak aynı zamanda ailenin ebeveynler arasında paylaştırılan işlevleri tek ebeveyn tarafından sağlanmakta ve bu durum farklı zorlukların hissedilmesine neden olmaktadır. Hem işlev ve fonksiyonlar açısından hem de çevresel etmenler ve değişen sosyal çevre ele alındığında hissedilen ve yaşanılan sorunlar daha çeşitli olabilmektedir. Dolayısıyla başta ekonomik problemler olmak üzere (özellikle de tek ebeveyn kadın olduğunda) sosyal, psikolojik ve çocukla ilgili problemler en temel problemler olarak tanımlanmıştır. Toplumumuzda evlilikle sosyal çevresini değiştiren kadınlar, özellikle boşanma ile farklı bir sosyal çevre ve ilişki biçimine girmektedirler. Bu değişim ekonomik yetersizlikler eklendiğinde dezavantajlılı̆̆ belirginleştirmektedir. $\mathrm{Bu}$ çerçevede tek ebeveynli ailelerin sorunlarını hafifletmeye yönelik çalışmalar önem kazanmaktadır. Aşağıdaki öneriler bu amaçla önemli görülmektedir; 
Yalova Sosyal Bilimler Dergisi

Tek ebeveynli ailelerin ve çocuklarının sosyal, psikolojik problemlerinin çözümüne ilişkin ücretsiz periyodik olarak danışmanlık almalarının sağlanması,

Ekonomik durumu iyi olmayan ailelerin maddi olarak desteklenmesi ve yapılacak yardımlarda öncelik tanınması,

$\checkmark$ Sosyal aktivitelere katılım konusunda sinırlılıkları bulunan ailelere aktiviteler ve/veya kurslar düzenlenmesi, tek ebeveynli ailelerin bir platformda buluşmalarının sağlanması, buna yönelik sosyal yaşam merkezlerinin açılması,

$\checkmark$ İhtiyaç nedeni ile çalışmak zorunda kalan ve küçük çocuğa sahip tek ebeveynlerin çocuklarını bırakıp işe gidebilecekleri kreş-gündüz bakım evi tahsis edilmesi veya bu ailelere hizmet verebilecek kreşlerle sorunun çözümüne yönelik anlaşma yapılması,

$\checkmark$ Hukuksal açıdan çocukların ve kadınların haklarını, açıklayacak biçimde ailelere hukuk danışmanlığı verilmesi (Boşanma, nafaka, velayet vb. konularda)

$\checkmark$ Meslek sahibi olmayan ve mesleği olmadığı için iş bulmakta sıkıntı yaşayan tek ebeveynlere Halk Eğitim iş birliği ile mesleki kurslar düzenlenmesi, sertifika verilmesi ve İş-Kur iş birliği ile kurs süresince kursiyerlere ücret verilmesi veya iş-kur aracılığı ile işe yerleştirilmelerinin sağlanması,

$\checkmark$ Mesleki kurslar sonucunda kendi işini kurmak isteyen kursiyerlere gerek KOSGEB (Küçük ve Orta Ölçekli İşletmeleri Geliştirme İdaresi Başkanlığı) veya Ticaret Odaları veya Kalkınma Ajansları gibi kurumlarla iş birliği yaparak, projeler oluşturulması, tek ebeveynli kadınların girişimci olmalarının sağlanması,

Belediyelerin uygun birimlerinde geçici veya sürekli işler için işçi alımında tek ebeveynlere öncelik tanınması gibi konular başta olmak üzere yapılabilecek yeni hizmetler hem ailenin işleyişi hem de genç kuşakların gelişimi için gerekli görülmektedir.

Son olarak tek ebeveynli ailelerin önemli bir kısmının kadın ve çocuklarından oluştuğu düşünüldüğünde dezavantajlılı̆g doğuran birden çok faktörün kadın olma ile birleşmesi sonucu ortaya çıkan sorunların toplumsal cinsiyete dayalı sorunlar ile birlikte ele alınması önemlidir. $\mathrm{Bu}$ açıdan yukarıda bahsedilen özellikle tek ebeveynli ailelerde çocuk bakımı ve çalışma arasındaki gerilimi azaltıcı çalışmalara ihtiyaç duyulmaktadır.

\section{Kaynakça}

Acar- Savran, G. - Demiryontan Tura, N. (2012), Kadının Görünmeyen Emeği, Yordam Kitap, İstanbul.

Aktay, Y. (1991), "Modern Dünyada Ailenin Dönüşümü ve Muhtemel Geleceği Üzerine Mülahazalar ve Geleneğe Dayalı Problemler", Aile Sosyolojisi Yazıları, Editör: Aydın, M. Açılım Kitap, İstanbul. 
Yalova Sosyal Bilimler Dergisi

Arslantürk, Z. (1995), Araştırma Metot ve Teknikleri, Marmara Üniversitesi İlahiyat Fakültesi Yayınları, İstanbul.

Atakan, A.S. (1991), "Boşanma Sürecinde Yaşanan Evreler”, Aile Yazlları 4, Evlilik Kurumu ve İlişkileri, Derleyen: Dikeçligil B. Çiğdem, A. T.C. Başbakanlık Aile ve Araştırma Kurumu, Semih Matbaacilık, Ankara.

Atakan, S. \& Korkut, Y. (1994), "Boşanmış Ailelerden Gelen Gençlerin Benlik Kavramı Ve Depresyon Seviyelerinin Çeşitli Değişkenler Açısından İncelenmesi ve Tam Aile Gençleri İle Karşılaştırılması”, Pedogoji Dergisi, Sayı 3. İstanbul Üniversitesi Edebiyat Fakültesi Basımevi, İstanbul.

Atila Demir, S.(2011), Aile ve Sosyal Sermaye İlişkisi, New World Sciences Academy, Humanities Sciences, 4C0128, V.6, N.4, 897-915.

Atila Demir, S.(2016), “Aile İçi Problemler: İletişimsizlik, Şiddet ve Boşanma”, Aile Sosyolojisi, Editörler: Nazmi Avc1- Erdal Aksoy, Lisans Yayıncılık, İstanbul.

Baş, T. \& Akturan, U. (2008), Nitel Araştırma Yöntemleri Nvivo 7,0 ile Nitel Veri Analizi, Seçkin Yayınları, Ankara.

Canatan K. (2011), “Aile Hakkında Kuramsal Perspektifler”, Aile Sosyolojisi, Editörler: Canatan, K. Yıldırım. E. Açılım Kitap, İstanbul.

Canatan K. (2011b), “Türk Ailesinin Tarihsel Gelişimi” Aile Sosyolojisi, Editörler: Canatan, K. Yıldırım. E. Açılım Kitap, İstanbul.

Çaki, F. (2016), “Farklılaşan Dünyada Aile Politikaları ve Ailenin Geleceği”, Aile Sosyolojisi, Editörler: Nazmi Avc1-Erdal Aksoy, Lisans Yayıncılık, İstanbul.

Danış, M. Z. (2006), "Davranış Bilimlerinde Ekolojik Yaklaşım”, Aile ve Toplum, Yı1: 8, Cilt: 3, Say1: 9, Ocak-Şubat-Mart 2006, (Erişim Tarihi: 03.07.2017), s: 45-48.

Dedeoğlu, S. (2000), “Toplumsal Cinsiyet Rolleri Açısından Türkiye'de Aile ve Kadın Emeği”, Toplum ve Bilim Dergisi, 86 Güz 2000, ss: 139-171.

Dinçoflaz, J.N. (2009), Kentteki Kadının Yoksulluğu ve Sosyal Yardımlaşma ve Dayanışma Genel Müdürlüğü'nün Kadın Yoksulluğuyla Mücadele Politikaları, T.C. Başbakanlık Sosyal Yardımlaşma ve Dayanışma Genel Müdürlüğü, SYDGM Yayınları, Ankara.

Giddens, A. (1997), Sosyoloji Eleştirel Bir Yaklaşım, Esengün. R.M., Derleyen: Öğretir İ. Birey Yayıncıl1k, İstanbul.

Giddens A. (2000), Sosyoloji, Çeviren: Özel H., Ayraç Yayınevi, Ankara.

Kalaycı, A. R. (2011), Tek Ebeveynli Aileler, T.C. Başbakanlık Aile ve Sosyal Araştırmalar Genel Müdürlüğü Yayınları, Ankara.

Kızılçelik, S. \& Erjem, Y. (1994), Açıklamalı Sosyoloji Terimler Sözlüğü, Atilla Kitabevi, Ankara.

Miller, B.C. (1996), Aile Araştırma Yöntemleri, Çev: Köksal D. T.C. Başbakanlık Aile Araştırma Kurumu Başkanlığı, Türk Tarih Kurumu Basımevi, Ankara.

OECD (2011), Doing Better for Families, http://www.oecd.org/els/family/47701118.pdf, Erişim: 24.02.2017.

Odabaşı, F. (2009), Yoksullukla Mücadelede İstihdamın Rolü. T.C Başbakanlık Sosyal Yardımlaşma Ve Dayanışma Derneği, SYDGM Yayınları, Ankara.

Öngider, Nilgün (2013), “Boşanmanın Çocuk Üzerine Etkileri”, Psikiyatride Güncel YaklaşımlarCurrent Approaches in Psychiatry 2013;5(2):140-161.

Ören, K. (2011), Sosyal Politika, Pelikan Yayınevi, Ankara.

Özkalp, E. (1993), Sosyolojiye Giriş, Eskişehir: Anadolu Üniversitesi, Sağlık ve Bilimsel Araştırma Çalışmaları Vakfı Yayınları, Eskişehir. 
Yalova Sosyal Bilimler Dergisi

Sarı, Ö. (2016), "Toplumsal Değişmenin Aileye Yansıması", Aile Sosyolojisi, Editörler: Nazmi Avc1-Erdal Aksoy, Lisans Yayıncılık, İstanbul.

Subaşı, N. (2014), “ Toplumsal Değişme, Aile ve Yeni Risk Alanları”, Aile Sosyolojisi Yazıları. Editör: Aydın. M., Açılım Kitap, İstanbul

T.C. Aile ve Sosyal Politikalar Bakanlığı (2014), Türkiye Boşanma Nedenleri Araştırması TBNA 2014, Proje Koordinatörü: Mustafa Turgut, Ankara.

TÜIK, Evlenme ve Boşanma İstatistikleri 2015,

http://www.tuik.gov.tr/PreHaberBultenleri.do?id=21515, 27.02.2017.

TÜIK, İstatistiklerle Aile 2015, http://www.tuik.gov.tr/PreHaberBultenleri.do?id=21523. Erişim Tarihi: 06.02.2017

Walczak, Y. \& Burns, S. (2004), Boşanma ve Çocuk Üzerine Etkileri, Çev: Ersevim İ. Özgür Yayınları, İstanbul.

Woolcock, M. and Narayan, D., (1999), Social Capital: Implications for Development Theory, Research and Policy, Final version submitted to the World Bank Research Observer, Vol. 15(2). 